\title{
NILAI-NILAI KEMANUSIAAN DAN PENDIDIKAN TOLERANSI BERAGAMA DALAM FILM BAJRANGI BHAIJAAN
}

\author{
Titin Setiani \& M. A. Hermawan \\ IAIN Purwokerto \\ Email: titinsetiani19@gmail.com \\ ajibsobo1@gmail.com
}

\begin{abstract}
In the context of education, there are several ways that can be used as a medium to convey messages of values, including movies. Bajrangi Bhaijaan, a Bollywood's movie, is an artistry that is full of educational and inspiring values. This article attempts to analyze the value of humanity and religious tolerance on the perspective of Education of Islamic Religious. The results of this study found that Bajrangi Bhaijaan's movie contains a strong message in promoting analyze the value of humanity and religious tolerance which consists of mutual help, loving, caring and not being arbitrary, respecting other beliefs, respecting places of worship and non-discriminating against others regarding on beliefs. The great values contained in this movie have a strong relevance to the development of Education of Islamic Religious so that if it is used as a learning resource it can contribute to the cultivation of moderate Islam in the school environment.
\end{abstract}

\begin{abstract}
Abstrak
Dalam konteks pendidikan, ada beberapa cara yang bisa dimanfaatkan sebagai media untuk menyampaikan pesan nilai-nilai toleransi, di antara adalah film. Film Bajrangi Bhaijaan, sebuah film produksi Bollywood merupakan karya seni yang penuh nilai edukasi dan menginspirasi. Artikel ini berusaha untuk menganalisis nilai kemanusiaan dan toleransi beragama dalam perspektif Pendidikan Agama Islam. Hasil dari penelitian ini menemukan bahwa film Bajrangi Bhaijaan mengandung pesan kuat dalam mempromosikan nilai kemanusiaan dan toleransi beragama yang terdiri dari tolong menolong, cinta kasih, peduli dan tidak semena-mena, menghargai keyakinan, menghargai tempat ibadah serta tidak membeda-bedakan orang lain terkait keyakinan. Nilai-nilai luhur yang terdapat dalam film ini memiliki relevansi yang kuat terhadap pengembangan Pendidikan Agama Islam sehingga jika dimanfaatkan sebagai sumber belajar bisa berkontribusi terhadap penanaman Islam yang moderat di lingkungan sekolah.
\end{abstract}

Kata kunci: nilai kemanusiaan, Pendidikan toleransi beragama, film Bajrangi Bhaijaan.

- $\quad$ Titin S. \& M. A. Hermawan - 105 
PIWULANG: Jurnal Pendidikan Agama Islam, Vol. 3 No. 2 Maret 2021, 105-122

P-ISSN : 2622-5638. E-ISSN : 2622-5654

Homepage: http://e-journal.staima-alhikam.ac.id/index.php/piwulang

\section{A. Latar Belakang}

Manusia diciptakan sebagai sebaik-baiknya makhluk di bumi. Manusia diberi anugerah oleh Tuhan sebagai makhluk berakal dan berbudi yang tidak dimiliki makhluk lain. Dengan akal dan budi tersebut manusia dapat menata kehidupan yang baik, teratur dan beradab. Akal budi tersebut yang melahirkan nilai-nilai kemanusiaan. Namun manusia sering lupa dengan anugerah tersebut sehingga kejahatan terus menerus terjadi dalam kehidupan kita. Kejahatan terjadi dalam berbagai bentuk seperti pembunuhan, penghinaan dan pembatasan hak pribadi seseorang. ${ }^{1}$

Penduduk Indonesia termasuk masyarakat yang majemuk akan keberagamannya, keadaan yang demikian hendaknya antara satu dengan yang lainnya dapat memahami sekaligus menghormati anutan atau keyakinan dari masing-masing pemeluk agama. Hal ini sangatlah penting dalam membangun keharmonisan kehidupan beragama. ${ }^{2}$ Dengan demikian semestinya kita memiliki sikap toleransi seperti tenggang rasa, menghargai perbedaan, menghormati satu sama lain dengan tetap menjunjung tinggi persatuan dan persaudaraan agar terwujud kehidupan damai.

Menjalin hubungan antar umat beragama yang majemuk seperti di Indonesia, hendaknya dikembangkan kerjasama antar umat beragama antara lain dalam memberikan intelektual atau pengetahuan, etik dan moral dengan tetap berpegang teguh pada keyakinan ajaran agama masingmasing. ${ }^{3}$ Dengan demikian akan menumbuhkan sikap toleransi, dimana toleransi merupakan kemampuan untuk menghormati sifat dasar, keyakinan, dan perilaku yang dimiliki orang lain. Dalam literature agama Islam, toleransi disebut tasamuh yang dipahami sebagai sifat atau sikap menghargai, membiarkan, atau membolehkan pendirian (pandangan) orang lain yang bertentangan dengan pandangan kita. 4 Toleransi merupakan modal utama dalam membangun kerukunan, tanpa adanya toleransi tidak mungkin ada sikap saling hormat-menghormati, kasihmengasihi dan gotong royong antar umat beragama ${ }^{5}$. Sikap toleransi tersebut harus dapat diwujudkan oleh semua anggota dan lapisan

\footnotetext{
${ }^{1}$ Lip D. Yahya, Gus Dur- Berbeda Itu Asyik, (Yogyakarta: Kansius, 2014), hlm. 1.

2 Jirhanuddin, Perbandingan Agama, (Yogyakarta: Pustaka Pelajar, 2010), hlm. 189.

${ }^{3}$ Haedar Nashir, Agama dan Krisis Kemanusiaan Modern, (Yogyakarta: Pustaka Pelajar, 1999), hlm. 101.

${ }^{4}$ Ngainun Naim \& Achmad Sauqi, Pendidikan Multikultural: Konsep dan Aplikasi, (Yogyakarta: ArRuzz Media, 2017), hlm, 75.

${ }^{5}$ Anita Khusnun Nisa' dan M. Wahid Nur Tualeka, Kajian Kritis Tentang Toleransi Beragama dalam Islam, Al-Hikmah: Jurnal Studi Agama-Agama, Vol 2, No. 2, 2016, hlm. 2.
} 
PIWULANG: Jurnal Pendidikan Agama Islam, Vol. 3 No. 2 Maret 2021, 105-122

P-ISSN : 2622-5638. E-ISSN : 2622-5654

Homepage: http://e-journal.staima-alhikam.ac.id/index.php/piwulang

masyarakat agar terbentuk masyarakat yang kompak namun beragam, sehingga kaya akan ide-ide baru.

Memperbaiki serta melangkah menuju Indonesia yang lebih baik, hendaklah pertama-tama penanaman nilai kemanusiaan dan sikap toleran dibangun melalui upaya pendidikan. ${ }^{6}$ Pendidikan adalah proses pembentukan sikap dan tingkah laku manusia baik secara individu maupun kelompok menuju pendewasaan mereka, melalui pengajaran dan latihan serta mengarahkan mereka agar mendapatkan pengetahuan dan pengertian. ${ }^{7}$ Maka dapat dikatakan pendidikan adalah salah satu sistem untuk mengubah sikap dan perilaku seseorang sebagai upaya untuk mendewasakan manusia.

Menumbuhkan sikap kemanusiaan dan toleransi tidaklah mudah, tidak hanya mengandalkan pendidikan yang diberikan di sekolah, faktor lingkungan juga sangat berpengaruh, seperti guru, orangtua dan masyarakat sekitar. Terlebih saat ini era globalisasi dan ilmu teknologi berkembang dengan pesat, mengakses informasi dapat dilakukan dimanapun dan kapanpun seperti di majalah, artikel, internet, televisi bahkan film yang mengandung nilai pendidikan dapat dijadikan media pembelajaran.

Film dapat dimanfaatkan sebagai media penyalur Pendidikan karena dengan media film biasanya pesan-pesan yang terkandung didalamnya akan lebih mudah diterima. Dalam film dapat dilihat secara langsung bagaimana gerak-gerik serta tingkah laku pemain sehingga memungkinkan pesan yang terkandung mudah untuk ditiru. Dalam konteks inilah film dapat dikatakan sebagai media yang efektif untuk memberikan contoh kepada masyarakat mengenai suatu hal.

Salah satu film yang memiliki pesan kuat terkait rasa kemanusiaan dan toleransi adalah film Bajrangi Bhaijaan, sebuah film India (Bollywood) yang diproduksi pada tahun 2015. Film ini mengisahkan perjuangan Pawan (Salman Khan) penganut Dewa Hanuman yang berasal dari India menyelamatkan seorang gadis kecil tunawicara bernama Shahida/Muni (Harshaali Malhotra) seorang muslim berasal dari Pakistan yang tersesat sendirian di negara India. Pawan mengantarkan Shahida pulang ke Pakistan dengan perjalanan yang tidak mudah, Ia melewati berbagai rintangan karena melewati negara yang sedang mengalami konflik dan adanya perbedaan agama.

${ }^{6}$ Muawanah, Pentingnya Pendidikan untuk Tanamkan Sikap Toleransi di Masyrakat, Jurnal Vijjacariya, Volume 5 Nomor 1, Tahun 2018, hlm, 59.

${ }^{7}$ Abd Aziz, Orientasi Sistem Pendidikan Agama di Sekolah, (Yogyakarta: Teras, 2010), hlm. 1-2.

- $\quad$ Titin S. \& M. A. Hermawan - 107 
PIWULANG: Jurnal Pendidikan Agama Islam, Vol. 3 No. 2 Maret 2021, 105-122

P-ISSN : 2622-5638. E-ISSN : 2622-5654

Homepage: http://e-journal.staima-alhikam.ac.id/index.php/piwulang

Film Bajrangi Bhaijaan menampilkan banyak adegan-adegan yang erat kaitannya dengan kemanusiaan dan keagamaan. Dalam film ini tergambarkan sikap kemanusiaan dan toleran yang dikemas melalui beberapa adegan, karakter tokoh dan alur cerita yang mengarah pada sebuah perdamaian antara negara India dan Pakistan. Film Bajrangi Bhaijaan memperlihatkan dua negara dengan ideologi, agama, dan karakter yang berbeda. Perbedaan tersebut ditambah dengan hubungan antar kedua negara yang sering terlibat konflik politik sangat berpotensi untuk menjadi kekuatan perusak. Namun di sisi lain sama kuatnya untuk menggerakkan orang agar berbuat baik, memiliki rasa kemanusiaan, saling mengerti dan toleransi untuk mewujudkan perdamaian dunia.

\section{B. Nilai Kemanusiaan dan Toleransi Beragama}

\section{Nilai Kemanusiaan}

Nilai kemanusiaan adalah nilai yang berhubungan dengan hakikat hidup manusia sebagai makhluk yang beragam kepentingan, keinginan dan harapan-harapan dan kebiasaan-kebiasaannya. 8 Manusia merupakan makhluk tertinggi diantara ciptaan Tuhan yang memiliki harkat dan martabat. Manusia yang sesungguhnya akan memiliki nilainilai kemanusiaan yang mencerminkan kedudukan manusia sebagai makhluk tertinggi diantara makhluk-makhluk lainnya.

Berbicara tentang nilai kemanusiaan, berarti tidak lepas dari manusia itu sendiri. Dengan kata lain, nilai tersebut muncul dilatarbelakangi oleh fenomena sosial yang terjadi di masyarakat. Jadi dapat dikatakan bahwa nilai kemanusiaan merupakan sesuatu yang lahir di tengah masyarakat karena adanya fenomena-fenomena sosial yang mampu memberikan pengaruh baik dan dampak positif bagi masyarakat. ${ }^{9}$ Nilai kemanusiaan penting untuk dikaji atau dianalisis karena nilai kemanusiaan akan diarahkan untuk pembentukan pribadi manusia sebagai makhluk sosial.

\section{Toleransi Beragama}

Toleransi berasal dari bahasa latin tolerantia yang berarti kelonggaran, kelembutan hati, keringanan, dan kesabaran. Tolerantia ini mulai dikenal secara luas di dataran Eropa, terutama pada masa Revolusi Perancis lantaran keterkaitannya dengan slogan kebebasan,

\footnotetext{
${ }^{8}$ Joko Untoro dan Tim Guru Indonesia, Buku Pintar Pelajaran SMA/MA IPS 6 In 1, (Jakarta: Wahyu media, 2010), hlm. 219.

${ }^{9}$ Agus Kichi Hermansyah, Nilai-Nilai Kemanusiaan dalam Buku 100 Cerita Anak Pilihan dan Kesesuaiannya Sebagai Bahan Pembelajaran Sastra di SD/MI, AL-IBTIDA : Jurnal Pendidikan Guru MI, Vol. 4 No. 1, Juni 2017, hlm. 18.
} 
PIWULANG: Jurnal Pendidikan Agama Islam, Vol. 3 No. 2 Maret 2021, 105-122

P-ISSN : 2622-5638. E-ISSN : 2622-5654

Homepage: http://e-journal.staima-alhikam.ac.id/index.php/piwulang

persamaan, dan persaudaraan. Kamus Umum Bahasa Indonesia mendefinisikan toleransi dengan kelapangdadaan, dalam artian suka kepada siapa pun, membiarkan orang berpendapat, atau berpendirian lain, tidak mau mengganggu kebebasan berpikir dan berkeyakinan orang lain. ${ }^{10}$

Islam sendiri mengenal toleransi dengan kata tasamuh yang artinya sikap membolehkan atau membiarkan ketidaksepakatan dan tidak menolak pendapat, sikap, ataupun gaya hidup yang berbeda dengan pendapat. Sikap toleransi tidak hanya dilakukan pada hal-hal yang menyangkut aspek spiritual dan moral yang berbeda, tetapi juga dilakukan pada aspek yang luas, seperti aspek ideologi dan politik yang berbeda. Tanpa adanya toleransi, berbagai pertentangan dan konflik akan sulit untuk dihindari. Sikap toleransi menunjuk pada adanya kerelaan untuk menerima kenyataan dengan keberadaan orang lain, yang berarti membiarkan sesuatu untuk dapat saling mengizinkan dan saling memudahkan.

Penggunaan sikap toleransi akan memunculkan adanya kedamaian dan kerukunan beragama. Keadaan damai diartikan sebagai tidak adanya perang atau kerusuhan, padahal saat ini memang tidak terjadi konflik secara langsung namun yang terjadi terdapat berbagai permasalahan secara internal dan latent pada keadaan yang masingmasing berusaha menjaga dan menahan diri, sehingga sikap toleransi perlu tetap dijaga melalui karakteristik kepribadian yang dapat memahami kemajemukan secara optimispositif serta memiliki kematangan agama. Bisa dipastikan, toleransi mengandung unsur ketenangan dan kedamaian yang terbangun atas prinsip keterbukaan dan penghargaan yang tinggi yang mengikat pada wujud nilai persaudaraan dan kemanusiaan. ${ }^{11}$

Perwujudan toleransi dalam pergaulan hidup antar umat beragama direalisasikan dengan cara yakni pertama, setiap penganut agama mengakui eksistensi agama-agama lain dan menghormati segala hak asasi penganutnya. Kedua, dalam pergaulan masyarakat setiap golongan umat beragama menampakka sikap saling mengerti, menghormati dan menghargai. ${ }^{12}$

\footnotetext{
${ }^{10}$ U. Abdullah Mumin, Pendidikan Toleransi Perspektif Pendidikan Agama Islam (Telaah Muatan Pendekatan Pembelajaran di Sekolah), Al-Afkar Journal for Islamic Studi, Vol. 1, No. 2, July 2018, hlm. 19.

${ }^{11}$ U. Abdullah Mumin,.., hlm. 20.

${ }^{12}$ Safrilsyah dan Mauliana, Sikap Toleransi Beragama di Kalangan Siswa SMA di Banda Aceh, Substansia, Volume 17 Nomor 1, April 2015, hlm. 108.
} 
PIWULANG: Jurnal Pendidikan Agama Islam, Vol. 3 No. 2 Maret 2021, 105-122

P-ISSN : 2622-5638. E-ISSN : 2622-5654

Homepage: http://e-journal.staima-alhikam.ac.id/index.php/piwulang

Berdasarkan uraian di atas, toleransi bermakna menahan diri, bersikap sabar, membiarkan orang lain berpendapat lain, dan berhati lapang terhadap orang-orang yang memiliki pendapat yang berbeda serta mengakui kebebasan serta hak-hak asasi para penganutnya. Sedangkan toleransi agama berarti pengakuan adanya kebebasan untuk menjalankan ibadatnya. Toleransi agama terbentuk oleh beberapa aspek dimana satu sama lain saling melengkapi, keempat aspek dalam toleransi yaitu: ${ }^{13}$

a. Membiarkan. Membiarkan setiap agama dalam berpartisipasi dan merefleksikan sikap atas agama mereka. Seperti adzan menggunakan pengeras suara di masjid-masjid dan masyarakat non-muslim membiarkan hal tersebut tanpa ikut campur didalamnya, baik merusak atau mencela.

b. Mengakui. Dalam toleransi mengakui setiap perbedaan prinsip yang ada dapat memberikan peluang yang besar dalam terjalinnya hubungan yang harmonis dan damai dalam sebuah masyarakat.

c. Menghormati. Sikap menghormati sangatlah penting karena dapat memberikan sebuah kehidupan yang aktif dalam bermasyarakat antar agama. Menghormati agama lain dalam beribadah dan dalam hal-hal lain itu sangatlah memberi efek positif antar penganut agama berbeda.

d. Mengizinkan. Mengizinkan berarti memberi izin, mengabulkan, membolehkan. Mengizinkan sikap atau tingkah laku seseorang untuk merealisasikan kehidupan bertoleran antar perbedaan agama yang ada dalam kehidupan social yang plural. Beberapa bentuk toleransi yang harus ditegakkan di lingkungan masyarakat seperti: 1). Mengakui hak setiap orang yakni Suatu sikap mental yang mengakui hak setiap orang didalam menentukan sikap atau tingkah laku dan nasibnya masing-masing. Misalnya hak beragama, hak mengikuti hati nurani, hak mengemukakan pendapat. 2). Menghormati keyakinan orang lain yang berarti memiliki sifat lapang dada seorang untuk menghormati dan membiarkan orang lain menjalankan ibadah sesuai agama yang dipeluknya tanpa mengganggu atau memaksa. 3). Agree in Disagreement. Setiap manusia mempunyai agama sebagai kepercayaan dan keyakinannya, meyakini dan mempercayai agama yang dipeluknya merupakan sikap yang wajar dan logis. Akan tetapi harus meyakini perbedaan-perbedaan agama yang dianut orang lain disamping itu juga persamaan-persamaan dengan agama yang dipeluknya. Sikap

${ }^{13}$ Safrilsyah dan Mauliana, Sikap Toleransi Beragama.. Hlm 108., 
PIWULANG: Jurnal Pendidikan Agama Islam, Vol. 3 No. 2 Maret 2021, 105-122

P-ISSN : 2622-5638. E-ISSN : 2622-5654

Homepage: http://e-journal.staima-alhikam.ac.id/index.php/piwulang

seperti ini akan menciptakan sikap (setuju didalam perbedaan) yang diharapkan dapat mengembangkan sikap toleransi dan kerukunan umat beragama. Dan 4). Saling mengerti satu sama lain akan mengakibatkan sikap saling menghormati, tidak akan terjadi saling membenci, mencaci, perebutan pengaruh seperti memengaruhi orang lain untuk memihak agamanya daripada agama lain.

\section{Nilai dan Pendidikan dalam Film}

Secara umum film adalah media komunikasi yang mampu mempengaruhi cara pandang individu yang kemudian akan membentuk karakter. Fungsi inilah yang ternyata sebagai pranata sosial, mempengaruhi tatanan sosial kemasyarakatan berbangsa dan bernegara.

Salah satu media yang turut memberikan kontribusi dalam pengembangan pendidikan adalah film. ${ }^{14}$ Film merupakan media yang amat besar kemampuannya dalam membantu proses belajar mengajar. Film mempunyai kemampuan untuk menghipnotis khalayak, sehingga khalayak selalu dapat menerima apa saja yang sudah disajikan di dalam film. Khalayak dapat terdorong untuk melakukan adegan yang ada di dalam film. Kepribadian anak dibentuk melalui pengalaman, anak yang lebih suka menonton adegan edukasi maka akan tumbuh menjadi orang yang baik namun tetap mendapat pengarahan dari guru atau orang tua.

Suatu nilai pendidikan yang terdapat di dalam film tidak lain bertujuan untuk merubah perilaku seseorang baik itu kognitif, afektif maupun psikomotorik. Tujuan pendidikan menurut Dewey ialah membentuk manusia untuk menjadi warga negara yang baik. Sehingga pendidikan hendaknya mempersiapkan anak didik untuk hidup di dalam masyarakat. Hidup di lingkungan masyarakat harus memiliki jiwa solidaritas sosial dimana harus memiliki karakter yang baik, budi pekerti, bermoral, menghargai satu sama lain dan sebagainya.

Tujuan pendidikan tidak selalu berpatokan dengan nilai-nilai angka yang diperoleh peserta didik dalam suatu pembelajaran. ${ }^{15}$ Penanaman nilai pendidikan seperti budi pekerti, moral/akhlak, toleransi, kemanusiaan tidak cukup hanya diberikan di sekolah sebagai pelajaran yang sifatnya hafalan atau lulus dengan ujian tertulis. Namun tujuan dari penanaman nilai-nilai tersebut agar anak didik dapat merealisasikan di kehidupan

\footnotetext{
${ }^{14}$ Safrilsyah dan Mauliana, Sikap Toleransi Beragama... Hlm. 108

${ }^{15}$ Lusiana Surya Widiani, dkk, Penerapan Media Film Sebagai Sumber Belajar Untuk Meningkatkan Kemampuan Mengolah Informasi Siswa Dalam Pembelajaran Sejarah, Factum: Jurnal Sejarah dan Pendidikan Sejarah, Vol. 7 No. 1, 2018, hlm. 124.
} 
PIWULANG: Jurnal Pendidikan Agama Islam, Vol. 3 No. 2 Maret 2021, 105-122

P-ISSN : 2622-5638. E-ISSN : 2622-5654

Homepage: http://e-journal.staima-alhikam.ac.id/index.php/piwulang

sehari-hari dan masyarakat yang diharapkan dapat menjadi karakter atau watak yang melekat.

Film bukan hanya sebagai tontonan melainkan juga dapat menjadi tuntunan. Film menjadi salah satu media yang berguna untuk mensosialisasikan segala apapun salah satunya nilai-nilai akhlak yang dapat diadopsi oleh penonton. ${ }^{16}$ Namun tidak semua film menyuguhkan nilainilai budi pekerti di dalamnya. Salah satu film India yaitu Bajrangi Bhaijaan menyuguhkan nilai-nilai kemanusiaan dan toleransi beragama. Di dalam film tersebut dapat ditemukan nilai-nilai kemanusiaan seperti tolong menolong, cinta kasih, peduli, tidak semena-mena terhadap sesama dan toleransi beragama seperti menghargai tempat ibadah, tolong menolong dan tidak membeda-bedakan orang yang berkeyakinan berbeda.

Nilai-nilai tersebut tidak cukup hanya diberikan sebagai pelajaran di sekolah yang sifatnya tekstual dan hanya mendengarkan ceramah guru. Namun dapat diarahkan pada objek yang nyata seperti menyaksikan langsung peristiwa-peristiwa yang nyata dalam bentuk lain seperti film yang kemudian dapat dijadikan contoh untuk kehidupan di masyarakat, karena dengan media film biasanya pesan-pesan yang terkandung didalamnya akan lebih mudah diterima.

Nilai sebuah pendidikan dalam film dimaknai sebagai pesan-pesan yang ditujukan kepada siapapun yang menyaksikan dan diharapkan dapat dijadikan contoh dan motivasi kepada manusia untuk bertindak lebih baik, karena hampir semua film memiliki makna mengajari dan memberitahu kita sesuatu.

\section{Deskripsi dan Sinopsis Film Bajrangi Bhaijan}

Film Bajrangi Bhaijaan merupakan film India yang sangat menginspirasi berkaitan tentang nilai kemanusiaan dan toleransi di kalangan masyarakat berbeda agama dan juga negara yang tengah terjadi konflik. Film ini dibintangi oleh artis Salman Khan, Kareena Kapoor, Nawazuddin Siddiqui serta Harshaali Malhotra, cerita ditulis oleh Vijayendra Prassad dan disutradarai oleh Kabir Khan serta diproduseri oleh Salman Khan dan Rockline Venkatesh.

Film Bajrangi Bhaijaan dirilis pada 17 Juli 2015, film dengan durasi dua jam tiga puluh sembilan menit tersebut menjadi hits terbesar Salman Khan sampai saat ini serta memecahkan rekor box office di India dan luar negeri. Film ini menjadi film India tercepat dalam memperoleh pendapatan

\footnotetext{
${ }^{16}$ Emza Ghazzali, dkk, Sosialisasi Nilai-Nilai Akhlak Melalui Film “Ada Surga Di Rumahmu”, Jurnal Studi Al-Qur'an Vol. 13, No. 2, Tahun 2017, hlm .178.
} 
PIWULANG: Jurnal Pendidikan Agama Islam, Vol. 3 No. 2 Maret 2021, 105-122

P-ISSN : 2622-5638. E-ISSN : 2622-5654

Homepage: http://e-journal.staima-alhikam.ac.id/index.php/piwulang

hingga satu milyar rupee pada pasar domestik dan menjadi film terlaris kedua di India dan film Bollywood terlaris kedua di pasar internasional.

Film ini berkisah tentang seorang gadis kecil usia 6 tahun dan bisu berpisah dari ibunya ketika akan kembali ke Pakistan, Shahida/Muni (Harshaali Malhotra) yang tersesat sendirian di India bertemu dengan Pawan Chaturvedi (Salman Khan) seorang penganut Dewa Bajrangbali (Dewa Hanuman). Tak tega melihat gadis yang bisu dan sendirian akhirnya Pawan menolongnya dengan membawa gadis tersebut ke rumah. Karena kondisi gadis tersebut bisu dan Pawan tidak mengetahui Namanya, maka Pawan memanggilnya dengan nama Munni.

Konflik bermula ketika Pawan bertemu dengan Shahida/Munni. Untuk mengetahui asal tempat tinggal Shahida/Munni, Pawan menyebutkan nama- nama kota yang ada di India, namun tak ada hasil. Asal tempat Shahida/Munni diketahui ketika keluarga Pawan sedang menonton pertandingan kriket antara India dan Pakistan. Ketika tim Pakistan menang, semua yang ada di rumah tersebut kecewa dan menyesali kemenangan Pakistan. Namun tidak dengan Shahida/Munni yang sangat gembira dan mencium televisi karena terdapat bendera Pakistan. Hal tersebut mencengangkan keluarga Pawan, ketika Pawan mengucap kata Pakistan, Shahida/Munni mengangguk tanda iya, ia berasal dari Pakistan.

Kejadian tersebut membuat ayah Rasika (calon mertua Pawan) marah dan meminta Pawan untuk segera mengembalikan Shahida/Munni ke negara asal. Proses Pawan mengantarkan Shahida pulang ke Pakistan tidaklah mudah. Ia melewati berbagai rintangan karena melalui negara yang sedang mengalami konflik juga karena adanya perbedaan agama. Mengantarkan Shahida pulang dengan jalur legal tidak berhasil karena tidak memiliki paspor, Pawan disarankan oleh ayah Rasika untuk memulangkan Shahida/Munni melalui agen perjalanan. Pawan mengusahakannya namun hasilnya mengecewakan,

Shahida/Munni tidak dipulangkan ke Pakistan namun dijual ditempat pelacuran. Hal tersebut membuat Pawan sangat marah. Akhirnya Pawan memilih mengantar sendiri Shahida/Munni walaupun dengan jalur illegal yang sangat berbahaya dengan taruhan nyawa, Pawan dibantu Boo Ali. Boo Ali merupakan orang yang mencari uang dengan membantu seseorang untuk melewati perbatasan dengan jalur illegal yaitu melalui terowongan bawah tanah. Ini sangat beresiko apabila ketahuan oleh tentara perbatasan. Ketika Boo Ali meminta bergegas melanjutkan perjalanan, Pawan berdiam diri dan menunggu tentara perbatasan menghampirinya untuk meminta ijin. Hal ini terlihat bodoh, namun Pawan adalah penganut Dewa Bajrangbali yang tidak boleh berbohong. Tentara perbatasan menghampiri dan menanyakan maksud tujuan Pawan, Pawan hanya ingin 
PIWULANG: Jurnal Pendidikan Agama Islam, Vol. 3 No. 2 Maret 2021, 105-122

P-ISSN : 2622-5638. E-ISSN : 2622-5654

Homepage: http://e-journal.staima-alhikam.ac.id/index.php/piwulang

meminta ijin untuk memasuki wilayah Pakistan, untuk mengantar Munni pulang namun tentara perbatasan memukulinya dan dianggap mata-mata. Namun karena Pawan tetap dalam pendiriannya dan meyakinkan tentaratentara tersebut akhirnya Pawan diijinkan masuk kawasan Pakistan.

Selama perjalanannya di Pakistan, Pawan dianggap mata-mata dari India sehingga menjadi buronan polisi. Konflik yang rumit berubah menjadi haru ketika Pawan dibantu oleh reporter bernama Chand Nawab yang diperankan oleh Nawazuddin Siddiqui yang awalnya mengira Pawan sebagai mata-mata, namun akhirnya membantu Pawan untuk menemukan keluarga Shahida, mereka juga dibantu oleh tokoh pemuka agama Pakistan (Maulana Sahab).

Mereka melanjutkan perjalanan, Chand Nawab lah yang menemukan keluarga Shahida, sementara Pawan sendiri tertangkap petugas polisi, dipenjara dan dipukuli sampai babak belur oleh petugas kepolisian Pakistan. Reporter Chand Nawab kemudian membuat video dan mnenggunggah ke internet tentang bagaimana perjalanan Pawan mengantarkan Shahida pulang ke Pakistan yang didasari cinta dan kasih saying, namun banyak terkendala karena perbedaan agama dan perseteruan dua negara India dan Pakistan. Vidoe tersebut kemudian ditonton oleh ribuan orang di kedua negara tersebut sehingga membangkitkan rasa simpati dari kedua negara. Melalui proses ini akhirnya Pawan dibebaskan dan dikembalikan ke India.

\section{E. Nilai Kemanusiaan dan Toleransi Beragama dalam Film Bajrangi Bhaijaan}

Terdapat beberapa adegan dalam film Bajrangi Bhaijaan yang mencerminkan nilai-nilai kemanusiaan dan pendidikan toleransi beragama yaitu sebagai table berikut:

\begin{tabular}{|c|l|l|l|}
\hline No & \multicolumn{1}{|c|}{ Nilai } & \multicolumn{1}{c|}{ Adegan } & \multicolumn{1}{c|}{ Keterangan } \\
\hline 1. & Tolong & Adegan di kedai setelah \\
Menolong & & $\begin{array}{l}\text { Pawan membelikan makanan kepada } \\
\text { gadis yang lusuh }\end{array}$ \\
\cline { 3 - 4 } & & $\begin{array}{l}\text { Adegan Ketika kondektur } \\
\text { mengantarkan Pawan ke } \\
\text { sebuah masjid }\end{array}$ & $\begin{array}{l}\text { Kondektur melindungi Pawan dan lainnya } \\
\text { dari kejaran polisi dengan memilihkan } \\
\text { tempat yang aman yakni masjid }\end{array}$ \\
\cline { 3 - 5 } & $\begin{array}{l}\text { Adegan ketika polisi datang } \\
\text { ke masjid untuk mencari } \\
\text { Pawan }\end{array}$ & $\begin{array}{l}\text { Maulana Sahab menolong Pawan dengan } \\
\text { melindunginya dari kejaran polisi }\end{array}$ \\
\hline 2. & Cinta Kasih & $\begin{array}{l}\text { Adegan Rasika meminta } \\
\text { Pawan segera } \\
\text { memulangkan Munni ke }\end{array}$ & $\begin{array}{l}\text { Merelakan uang tabungan untuk membeli } \\
\text { rumah sebagai syarat pernikahan. Namun } \\
\text { lebih mementingkan gadis kecil untuk } \\
\text { pulang ke negaranya. }\end{array}$ \\
\hline
\end{tabular}

- $\quad$ Titin S. \& M. A. Hermawan - 114 
PIWULANG: Jurnal Pendidikan Agama Islam, Vol. 3 No. 2 Maret 2021, 105-122

P-ISSN : 2622-5638. E-ISSN : 2622-5654

Homepage: http://e-journal.staima-alhikam.ac.id/index.php/piwulang

\begin{tabular}{|c|c|c|c|}
\hline & & $\begin{array}{l}\text { Pakistan menggunakanuang } \\
\text { tabungan pembelian rumah }\end{array}$ & \\
\hline \multirow[t]{2}{*}{3.} & \multirow[t]{2}{*}{ Peduli } & $\begin{array}{l}\text { Adegan setelah Pawan } \\
\text { ditipu Agen perjalanan }\end{array}$ & $\begin{array}{l}\text { Pawanmemutuskan untuk mengantar } \\
\text { Shahida/Munni pulang ke Pakistan } \\
\text { walaupun tidak memilikipassport maupun } \\
\text { visa }\end{array}$ \\
\hline & & $\begin{array}{l}\text { Adegan Chand Nawab } \\
\text { mengunggahsebuah video } \\
\text { ke youtube }\end{array}$ & $\begin{array}{l}\text { Chand Nawab memengaruhi masyarakat } \\
\text { Pakistan dan India untuk simpati atau } \\
\text { peduli dengan Pawan karena Pawan } \\
\text { dipenjara atas kesalahpahaman }\end{array}$ \\
\hline \multirow[t]{2}{*}{4.} & \multirow[t]{2}{*}{$\begin{array}{l}\text { Tidak } \\
\text { Semena- } \\
\text { mena }\end{array}$} & $\begin{array}{l}\text { Adegan ketika Pawan dan } \\
\text { Shahida/Munni menaiki Bus } \\
\text { setelah di kejar-kejar polisi } \\
\text { Pakistan }\end{array}$ & $\begin{array}{l}\text { Kondektur tidak semena- mena } \\
\text { menghakimi Pawan sebagai mata- mata } \\
\text { karena ia berasal dari India dan } \\
\text { memasuki wilayah Pakistan secara illegal }\end{array}$ \\
\hline & & $\begin{array}{l}\text { Adegan Pawan berada di } \\
\text { jeruji besi dan dipukuli }\end{array}$ & $\begin{array}{l}\text { Khamid Khan tidak semena-mena } \\
\text { membiarkan Pawan terpenjara seumur } \\
\text { hidup di Pakistan karena ini akan } \\
\text { menodai kehormatan negara Pakistan }\end{array}$ \\
\hline \multirow[t]{2}{*}{5.} & \multirow[t]{2}{*}{$\begin{array}{l}\text { Menghargai } \\
\text { Keyakinan } \\
\text { Orang Lain }\end{array}$} & $\begin{array}{l}\text { Adegan Munni hilang dan } \\
\text { ditemukan di rumah orang } \\
\text { muslim sedang makan } \\
\text { ayam }\end{array}$ & $\begin{array}{l}\text { Melihat Shahida/Munni memakan daging, } \\
\text { maka Pawan beranggapan dia bukan dari } \\
\text { kasta Brahmana melainkan dari kasta } \\
\text { Ksatria. }\end{array}$ \\
\hline & & $\begin{array}{l}\text { Adegan Pawan sampai di } \\
\text { wilayah perbatasan } \\
\text { Pakistan- India kemudian } \\
\text { bertemu tantara perbatasan. }\end{array}$ & $\begin{array}{l}\text { Pawan sebagai pengikut Bajrangbali yang } \\
\text { akan selalu jujur sehingga diijinkan oleh } \\
\text { pimpinan tentara untuk melewati } \\
\text { perbatasan }\end{array}$ \\
\hline 6. & $\begin{array}{l}\text { Tolong } \\
\text { Menolong }\end{array}$ & $\begin{array}{l}\text { Adegan ketika Pawan } \\
\text { menyadari bahwa Munni } \\
\text { orang Islam. }\end{array}$ & $\begin{array}{l}\text { Rasika mengingatkan Pawan bahwa } \\
\text { dalam menolong seseorang tak perlu } \\
\text { mempertimbangkan apa agamanya. }\end{array}$ \\
\hline 7. & $\begin{array}{l}\text { Menghargai } \\
\text { Tempat } \\
\text { lbadah } \\
\text { Orang Lain }\end{array}$ & $\begin{array}{l}\text { Adegan setelah bermalam } \\
\text { di masjid, paginya Pawan } \\
\text { bangun karena } \\
\text { ditertawakan anak-anak }\end{array}$ & $\begin{array}{l}\text { Pawan menghargai tempat suci agama } \\
\text { lain sehingga la pergi keluar masjid } \\
\text { karena ia menyadari bahwa ia bukan } \\
\text { orang Islam }\end{array}$ \\
\hline \multirow[t]{3}{*}{8.} & \multirow{3}{*}{$\begin{array}{l}\text { Tidak } \\
\text { Membeda- } \\
\text { bedakan } \\
\text { Seseorang } \\
\text { yang } \\
\text { Berkaitan } \\
\text { dengan } \\
\text { Keyakinan. }\end{array}$} & $\begin{array}{l}\text { Adegan Pawan tidak mau } \\
\text { masuk kedalam masjid }\end{array}$ & $\begin{array}{l}\text { Maulana Sahab mengajak Pawan masuk } \\
\text { kedalam masjid karena masjid terbuka } \\
\text { untuk setiap orang sekalipun berbeda } \\
\text { agama }\end{array}$ \\
\hline & & $\begin{array}{l}\text { Adegan Pawan dan lainnya } \\
\text { melanjutkan perjalanan }\end{array}$ & $\begin{array}{l}\text { Maulana Sahab tetap mendoakan yang } \\
\text { terbaik untuk Pawan walaupun Pawan } \\
\text { berbeda agama }\end{array}$ \\
\hline & & $\begin{array}{l}\text { Adegan sebelum berpisah, } \\
\text { Maulana Sahab spontan } \\
\text { gerakkan tubuhnya seolah- } \\
\text { olah melakukan ucapan } \\
\text { salam yang biasa dilakukan }\end{array}$ & $\begin{array}{l}\text { Maulana Sahab mengucapkan salam } \\
\text { seperti yang Pawan lakukan. }\end{array}$ \\
\hline
\end{tabular}

- $\quad$ Titin S. \& M. A. Hermawan - 115 
PIWULANG: Jurnal Pendidikan Agama Islam, Vol. 3 No. 2 Maret 2021, 105-122

P-ISSN : 2622-5638. E-ISSN : 2622-5654

Homepage: http://e-journal.staima-alhikam.ac.id/index.php/piwulang

\begin{tabular}{|l|l|l|}
\hline & $\begin{array}{l}\text { orang Islam kepada Pawan, } \\
\text { Chand Nawab, dan Munni }\end{array}$ & \\
\cline { 2 - 3 } & $\begin{array}{l}\text { Adegan Pawan pergi ke } \\
\text { tempat suci Hazrat Amin } \\
\text { Shah Dargah. }\end{array}$ & $\begin{array}{l}\text { Pawan yang mengatakan ia rela ke } \\
\text { tempat suci manapun demi bisa } \\
\text { mengantarkan Munni Kembali pulang } \\
\text { dan bertemu dengan orang tuanya }\end{array}$ \\
\hline
\end{tabular}

\section{F. Kontribusi Film Bajrangi Bhaijaan Terhadap Nilai Kemanusiaan dan Pendidikan Toleransi Beragama}

Nilai kemanusiaan yang terkandung di dalam film tersebut adalah tolong menolong sesama manusia, cinta kasih, peduli dan tidak semenamena terhadap orang lain. Salah satu nilai kemanusiaan ditunjukkan Pawan yang membelikan makanan untuk gadis kecil yang tersesat. Ketika anak didik melihat peristiwa tersebut maka secara tidak langsung mereka sudah mendapat pendidikan yaitu sesama manusia harus tolong menolong, ada sisi kepedulian serta cinta kasih dan tidak semena-mena. Setelah mencermati peristiwa tersebut, diharapkan anak didik dapat mengamalkannya di lingkungan sekolah, keluarga atau masyarakat. Misalnya teman sebangku tidak membawa bekal makanan maka sebagai teman yang baik kita harus berbagi makanan, hal tersebut menunjukkan kepedulian, kasih sayang dan tolong menolong.

Sedangkan nilai toleransi beragama yang terkandung yaitu menghargai tempat ibadah, tolong menolong, menghargai keyakinan orang lain serta tidak membeda-bedakan orang lain terkait kepercayaan. Negara Indonesia memiliki ragam agama yang secara tidak langsung hidup saling berdampingan. Oleh karena itu memiliki sikap tenggang rasa sangat diperlukan dan ditanamkan sejak dini. Film Bajrangi Bhaijaan mengajarkan kita untuk memandang bahwa manusia itu sama walaupun berbeda negara, ras, suku, budaya, agama. Sesama manusia harus memiliki jiwa sosial dan tenggang rasa sehingga terwujud kehidupan damai.

Menonton film Bajrangi Bhaijaan secara tidak langsung kita sudah mendapat pendidikan, namun apabila dijadikan media pembelajaran oleh guru atau orang tua serta mendapatkan pengarahan maka anak akan lebih mudah memahami sebuah arti kemanusiaan dan toleransi agama karena pendidikan melalui film lebih jelas dan mudah dipahami daripada hanya teori di kelas. Anak didik akan lebih mudah meniru karena melihat langsung peristiwa serta mendapat arahan dari guru atau orang tua.

Tujuan pendidikan adalah menciptakan seseorang yang berkualitas dan berkarakter sehingga memiliki pandangan yang luas ke depan untuk mencapai suatu cita-cita yang diharapkan dan mampu beradaptasi secara 
PIWULANG: Jurnal Pendidikan Agama Islam, Vol. 3 No. 2 Maret 2021, 105-122

P-ISSN : 2622-5638. E-ISSN : 2622-5654

Homepage: http://e-journal.staima-alhikam.ac.id/index.php/piwulang

tepat dan cepat di dalam berbagai lingkungan. ${ }^{17}$ Berdasarkan tujuan tersebut anak didik harus memiliki karakter sejak dini agar mampu beradaptasi sesuai norma di lingkungan masyarakat, sedangkan kita tahu kondisi Indonesia yang multikultural \& plural. Oleh karena itu sangat penting menanamkan dan mengembangkan nilai kemanusiaan dan toleransi beragama pada setiap individu.

Pendidikan Agama Islam memiliki tanggungjawab untuk membentuk karakter individu yang baik guna menjadi pribadi yang religius dan memiliki karakter sosial yang bernafaskan nilai-nilai Islam. Dengan harapan, jika proses pembelajaran Pendidikan Agama Islam berjalan dengan baik, maka akan melahirkan masyarakat yang tidak hanya maju dalam pengetahuan tetapi menjadi manusia yang beradab. ${ }^{18}$

Penggunaan film sebagai sumber pendidikan tidak hanya menarik perhatian anak didik namun juga memberikan dorongan psikologis kepada anak didik untuk menerapkan nilai-nilai dalam kehidupan sehari-hari. Film dapat digunakan dalam pengembangan Pendidikan Agama Islam. Dalam pembelajaran Pendidikan Agama Islam dapat digunakan untuk mengajarkan pengembangan aspek sikap atau nilai-nilai maupun keterampilan seperti keterampilan sholat, manasik haji, nilai budi pekerti dan sebagainya.

\section{G. Relevansi Film Bajrangi Bhaijaan Terhadap Pendidikan Agama Islam} (PAI)

Pendidikan Agama berfungsi membentuk manusia yang beriman dan bertakwa kepada Tuhan Yang Maha Esa serta berakhlak mulia dan mampu menjaga kedamaian, kerukunan hubungan intern ataupun antar umat beragama. 19 Dalam kehidupan sehari-hari, manusia hidup saling berdampingan dan membutuhkan manusia lain yang kita ketahui bahwa manusia beragam pola pikir, sifat, sikap, keyakinan dan sebagainya. Oleh karena itu sangat diperlukan sikap humanis dan toleran dalam menjalankan hidup agar paham bagaimana seharusnya menyikapi perbedaan.

Film Bajrangi Bhaijaan menggambarkan tentang sikap kemanusiaan dan sikap toleran yang menunjukkan usaha yang sesuai untuk mencapai Pendidikan Agama Islam, dimana kita ketahui dalam pembelajaran PAI yang notebenenya adalah pendidikan nilai maka ada banyak nilai yang ditanamkan kepada peserta didik. Kemudian nilai ini yang nanti menjadi

\footnotetext{
${ }^{17}$ Muawanah, Pentingnya Pendidikan untuk Tanamkan Sikap Toleransi di Masyrakat. Jurnal Vijjacariya., hlm. 57.

${ }^{18}$ Muawanah, Pentingnya Pendidikan,... hlm. 148.

${ }^{19}$ Soemanto,dkk, Eksperimen Pendidikan Agama Berwawasan Kerukunan, (Jakarta: Pena citrasatri, 2008), hlm.4.
} 
PIWULANG: Jurnal Pendidikan Agama Islam, Vol. 3 No. 2 Maret 2021, 105-122

P-ISSN : 2622-5638. E-ISSN : 2622-5654

Homepage: http://e-journal.staima-alhikam.ac.id/index.php/piwulang

acuan dalam bertindak dan bersikap. Nilai-nilai yang mengandung keteraturan hubungan antar sesama manusia sangat mendapat perhatian dalam dunia pendidikan Islam. ${ }^{20}$ Terdapat relevansi yang sangat kuat dari pesan kemanusiaan dan toleransi beragama yang terdapat dalam film Bajrangi Bhaijaan dengan PAI yang diajarkan di sekolah.

1) Nilai-nilai kemanusiaan

a. Tolong menolong

Tolong menolong merupakan sikap yang ditunjukkan seseorang dalam tindakan untuk membantu meringankan beban orang lain. Q.S. Al-Maidah: 2 mengisyaratkan dengan jelas tentang hal ini. Allah SWT memerintah kepada manusia untuk senantiasa tolong menolong dalam hal kebaikan, baik yang berhubungan dengan Tuhan maupun sesama manusia.

b. Cinta kasih

Cinta kasih atau kasih sayang merujuk kepada perasaan cinta sesama manusia baik kepada diri sendiri dan orang lain. Kasih sayang merupakan salah satu sifat Allah yaitu Ar-Rahman yang banyak dicantumkan di Al-Qur'an. Oleh karena itu, manusia juga harus memiliki sifat kasih sayang kepada sesama walaupun berbeda suku, ras, agama. Cerminan sikap ini terdapat dalam Q.S. Maryam: 96.

Ayat tersebut menjelaskan bahwa orang yang beriman kepada Allah dan rasul-Nya serta beramal shaleh maka Allah akan menanamkan rasa kasih sayang terhadap hati mereka. Manusia akan memiliki rasa kasih sayang apabila selalu dibiasakan melakukan hal-hal yang baik, kasih sayang merupakan salah satu akhlak mulia manusia baik terhadap diri sendiri, sesama manusia maupun makhluk lain serta lingkungan alam sekitar.

c. Peduli

Peduli merupakan sikap melibatkan diri terhadap persoalan, keadaan atau kondisi yang terjadi di sekitar kita. peduli juga merupakan sikap yang mengedepankan nilai-nilai kemanusiaan yang membantu siapa saja yang sedang mengalami kesulitan. Mereka yang memiliki kepedulian merupakan orang yang terpanggil untuk membantu mengatasi kesulitan yang dihadapi orang lain dalam rangka memberi inspirasi, perubahan, kebaikan terhadap lingkungan sekitar. Contoh kepedulian dalam kehidupan sehari-hari misalnya berzakat, berinfaq, shadaqoh. Hal-hal tersebut

${ }^{20}$ A. Qodri A. Azizy, Pendidikan Agama untuk Membangun Etika Sosial (Mendidik Anak Sukses Masa Depan: Pandai dan Bermanfaat), (Semarang: Aneka Ilmu, 2003), hlm. 25. 
PIWULANG: Jurnal Pendidikan Agama Islam, Vol. 3 No. 2 Maret 2021, 105-122

P-ISSN : 2622-5638. E-ISSN : 2622-5654

Homepage: http://e-journal.staima-alhikam.ac.id/index.php/piwulang

sangat diperintahkan dalam agama Islam agar terbiasa berbuat baik, mengindari kesenjangan sosial antara orang kaya dengan kaum dhuafa, membersihkan diri dari akhlak buruk, juga sebagai rasa syukur atas nikmat Allah yang diberikan.

d. Tidak semena-mena

Kita tidak boleh memiliki sikap semena-mena terhadap manusia bahkan menyakiti, kita harus kontrol diri. Apabila saling menyakiti maka hidup tidak akan rukun dan damai, maka dari itu tidak boleh berbuat semena-mena kepada sesama manusia karena manusia memiliki hak masing-masing. Allah menegaskannya dalam Q.S. Asy-Syura: 42. Ayat tersebut menjelaskan bahwa orang yang berbuat dzalim di muka bumi maka mereka akan mendapat azab yang pedih. Berbuat semena-mena merupakan perbuatan yang dzalim, perbuatan yang dzalim akan mendapat dosa kelak di akhirat. Oleh karena itu, Islam melarang manusia untuk berbuat semena-mena. Biasakan melakukan perbuatan yang positif seperti menghargai pendapat orang lain walaupun berbeda pendapat serta tidak mencela, selalu rendah hati, menganggap semua orang itu sama, dan sebagainya.

2) Sikap Toleransi

Islam mengenal toleransi dengan kata tasamuh yang artinya sikap membolehkan atau membiarkan ketidaksepakatan dan tidak menolak pendapat, sikap, ataupun gaya hidup yang berbeda dengan pendapat. Sikap toleransi tidak hanya dilakukan pada hal-hal yang menyangkut aspek spiritual dan moral yang berbeda, tetapi juga dilakukan pada aspek yang luas, seperti aspek ideologi dan politik yang berbeda. Tanpa adanya toleransi, berbagai pertentangan dan konflik akan sulit untuk dihindari. Sikap toleransi menunjuk pada adanya kerelaan untuk menerima kenyataan dengan keberadaan orang lain, yang berarti membiarkan sesuatu untuk dapat saling mengizinkan dan saling memudahkan.

Q.S. Al-kafirun: 1-6 merupakan salah satu surah yang mengajarkan kita untuk bertoleransi antar umat. Menghormati penganut agama lain seperti pada ayat terakhir "untukmu agamamu dan untukku agamaku". Dalam surah tersebut ditegaskan bahwa umat muslim tidak akan menyembah apa yang orang kafir sembah, begitupun sebaliknya. Umat muslim tidak akan pernah menjadi penyembah apa yang disembah orang kafir, begitupun sebaliknya. Toleransi awal adanya kerukunan, tanpa adanya toleransi tidak mungkin ada sikap saling hormat- 
PIWULANG: Jurnal Pendidikan Agama Islam, Vol. 3 No. 2 Maret 2021, 105-122

P-ISSN : 2622-5638. E-ISSN : 2622-5654

Homepage: http://e-journal.staima-alhikam.ac.id/index.php/piwulang

menghormati, kasih-mengasihi dan gotong royong antar umat beragama. ${ }^{21}$ Semangat toleransi juga terdapat dalam Q.S. al-Hujurat: 13.

Dijelaskan bahwa sesungguhnya Allah SWT menciptakan manusia dari satu laki-laki yaitu Adam dan satu wanita yaitu Hawa. Jadi sebenarnya nasab kita satu, maka janganlah sebagian dari kalian menghina nasab sebagian yang lain. Dan kemudian dijadikan suku-suku yang banyak dan bangsa-bangsa agar sebagian dari kita mengenal sebagian yang lain, bukan untuk saling merasa lebih tinggi, karena kedudukan yang tinggi itu hanya didapat dengan ketakwaan. Sesungguhnya orang yang paling mulia di sisi Allah adalah orang yang paling bertakwa.

Film Bajrangi Bhaijaan mengajarkan kita untuk bertoleransi dengan menghormati keyakinan orang lain, menghargai tempat ibadah, tidak membeda-bedakan dan tolong menolong. Dengan hal tersebut kita dapat mencontohnya untuk bertindak dan berperilaku di masyarakat yang majemuk. Misalnya menolong orang yang terkena musibah tanpa mempermasalahkan keyakinan, menghormati teman yang berbeda keyakinan, tidak mencela atau merusak fasilitas tempat ibadah orang lain yang berbeda keyakinan, tidak membeda-bedakan teman dalam bergaul atau berteman dengan siapa saja. Orang Islam diperbolehkan membantu orang kafir dalam masalah urusan duniawi, seperti menjenguk ketika sakit, ta'ziah, dan bertamu. Selain itu, untuk urusan akidah Islam melarang adanya sikap toleransi.

\section{H. Kesimpulan}

Film Bajrangi Bhaijaan sebagai sebuah karya seni memiliki pesan yang kuat terkait nilai kemanusiaan dan toleransi beragama. Terdapat beberapa nilai kemanusiaan yang bisa digali dari film ini, di antaranya adalah tolong menolong, cinta kasih, peduli sesama, tidak semena-mena, dan toleransi. Nilai-nilai tersebut merupakan fondasi dalam membangun kehidupan bersama di tengah keragaman dan perbedaan. Dalam konteks pengembangan PAI, film ini memiliki relevansi yang kuat karena pesan kemanusiaan dan toleransi beragama yang terdapat dalam film ini juga merupakan ajaran yang Islam yang harus ditanamkan kepada peserta didik. Terlebih lagi dengan semangat pendidikan moderasi Islam, film ini akan memberikan inspirasi dan memberikan kontribusi signifikan terhadap upaya internalisasi nilai-nilai Islam wasathiyah di lingkungan sekolah.

${ }^{21}$ Anita Khusnun Nisa’ dan M. Wahid Nur Tualeka, Op.cit., hlm. 2. 
PIWULANG: Jurnal Pendidikan Agama Islam, Vol. 3 No. 2 Maret 2021, 105-122

P-ISSN : 2622-5638. E-ISSN : 2622-5654

Homepage: http://e-journal.staima-alhikam.ac.id/index.php/piwulang

\section{Daftar Pustaka}

Azizy, A. Qodri A. 2003. Pendidikan Agama untuk Membangun Etika Sosial (Mendidik Anak Sukses Masa Depan: Pandai dan Bermanfaat). Semarang: Aneka Ilmu.

Ghazzali, Emza dkk. Sosialisasi Nilai-Nilai Akhlak Melalui Film "Ada Surga Di Rumahmu”. Jurnal Studi Al-Qur'an Vol. 13, No. 2, Tahun 2017.

Hafid, Anwar dkk. 2013. Konsep Dasar Ilmu Pendidikan. Bandung: Alfabeta.

Handayani, Muslih Aris. Studi Peran Film dalam Dunia Pendidikan. Insania Jurnal Pemikiran Kependidikan. Vol. 11 No. 2 Januari-April 2006.

Harahap, Nursapia. Penelitian Kepustakaan, Jurnal Iqra Vol. 08 No. 01, 2014.

Hermansyah, Agus Kichi. Nilai-Nilai Kemanusiaan dalam Buku 100 Cerita Anak Pilihan dan Kesesuaiannya Sebagai Bahan Pembelajaran Sastra di SD/MI, AL-IBTIDA : Jurnal Pendidikan Guru MI, Vol. 4 No. 1, Juni 2017.

Jirhanuddin. 2010. Perbandingan Agama. Yogyakarta: Pustaka Pelajar.

Khusnun Nisa', Anita dan M. Wahid Nur Tualeka. Kajian Kritis Tentang Toleransi Beragama dalam Islam. Al-Hikmah: Jurnal Studi AgamaAgama, Vol 2, No. 2, 2016.

Lusiana Surya Widiani, dkk. Penerapan Media Film Sebagai Sumber Belajar Untuk Meningkatkan Kemampuan Mengolah Informasi Siswa Dalam Pembelajaran Sejarah, Factum: Jurnal Sejarah dan Pendidikan Sejarah, Vol. 7 No. 1, 2018.

Muawanah. Pentingnya Pendidikan untuk Tanamkan Sikap Toleransi di Masyrakat. Jurnal Vijjacariya, Volume 5 Nomor 1, Tahun 2018.

Mumin, U. Abdullah Pendidikan Toleransi Perspektif Pendidikan Agama Islam (Telaah Muatan Pendekatan Pembelajaran di Sekolah). Al- Afkar Journal for Islamic Studi, Vol. 1, No. 2, July 2018

Naim, Ngainun \& Achmad Sauqi. 2017. Pendidikan Multikultural: Konsep dan Aplikasi. Yogyakarta: Ar-Ruzz Media.

Nashir, Haedar. 1999. Agama dan Krisis Kemanusiaan Modern. Yogyakarta: Pustaka Pelajar.

Rianto, Hadi. Implementasi Nilai Kemanusiaan yang Adil dan Beradab di Lingkungan Sekolah. Sosial Horizon: Jurnal Pendidikan Sosial Vol. 3, No. 1, Juni 2016.

Safrilsyah dan Mauliana. Sikap Toleransi Beragama di Kalangan Siswa SMA di Banda Aceh. Substansia, Volume 17 Nomor 1, April 2015. 
PIWULANG: Jurnal Pendidikan Agama Islam, Vol. 3 No. 2 Maret 2021, 105-122

P-ISSN : 2622-5638. E-ISSN : 2622-5654

Homepage: http://e-journal.staima-alhikam.ac.id/index.php/piwulang

Soemanto, dkk. 2008. Eksperimen Pendidikan Agama Berwawasan Kerukunan. Jakarta: Pena citrasatri.

Untoro, Joko dan Tim Guru Indonesia. 2010. Buku Pintar Pelajaran SMA/MA IPS 6 In 1. Jakarta: Wahyu media.

Yahya, Lip D. 2014. Gus Dur: Berbeda Itu Asyik. Yogyakarta: Kansius. 